\title{
PENGARUH MODEL PEMBELAJARAN THINK PAIR SHARE BERBANTUAN POWER POINT TERHADAP HASIL BELAJAR IPA
}

\author{
Putu Santra1,*, I Made Citra Wibawa ${ }^{2}$, Ni Wayan Rati ${ }^{3}$ \\ 1 Jurusan Pendidikan Guru Sekolah Dasar Universitas Pendidikan Ganesha \\ 2 Jurusan Pendidikan Guru Sekolah Dasar Universitas Pendidikan Ganesha \\ 3 Jurusan Pendidikan Guru Sekolah Dasar Universitas Pendidikan Ganesha
}

\begin{abstract}
Abstrak
Penelitian ini bertujuan untuk mengetahui perbedaan hasil belajar IPA yang signifikan antara siswa yang mengikuti model pembelajaran think pair share berbantuan power point dan siswa yang mengikuti pembelajaran dengan model pembelajaran konvensional pada siswa kelas V di SD Gugus I Kecamatan Kubutambahan pada tahun pelajaran 2016/2017. Populasi penelitian adalah siswa kelas V di SD Gugus I Kecamatan Kubutambahan tahun pelajaran 2016/2017. Sampel penelitian ialah SD Negeri 1 Bukti yang berjumlah 20 siswa dan SD Negeri 8 Kubutambahan yang berjumlah 21 siswa. Data hasil belajar IPA siswa dikumpulkan dengan instrumen tes (pilihan ganda), kemudian dianalisis dengan menggunakan statistik deskriptif dan statistik inferensial uji-t. Berdasarkan hasil analisis data, disimpulkan bahwa terdapat perbedaan hasil belajar IPA yang signifikan antara yang mengikuti kegiatan pembelajaran dengan menggunakan model pembelajaran think pair share berbantuan power point dan siswa yang mengikuti kegiatan pembelajaran dengan menggunakan model pembelajaran konvensional.
\end{abstract}

\author{
Keywords: \\ Hasil Belajar, IPA, \\ Powerpoint, Think Pair \\ Share
}

\section{PENDAHULUAN}

Pada era yang serba globalisasi ini, kita dituntut untuk dapat bersaing pada segala aspek kehidupan. Untuk mampu bersaing di era ini, tentunya tidak terlepas dari kualitas sumber daya manusia. Kualitas sumber daya manusia selalu dituntut untuk selalu menjadi lebih baik dari sebelumnya. Salah satu cara meningkatkannya ialah melalui bidang pendidikan. Pendidikan pada dasarnya merupakan interaksi antara pendidik dengan peserta didik untuk mencpai tujuan pendidikan, yang berlangsung dalam lingkungan tertentu (Mudjrimin, 2013). Pendidikan memegang peranan penting untuk kemajuan dan perkembangan sumber daya manusia. Untuk meningkatkan kualitas sumber daya manusia secara maksimal, diperlukan sistem pendidikan yang baik dan selalu diperbaharui sesuai dengan perkembangan ilmu pengetahuan dan teknologi. Mutu pendidikan yang berkualitas sangat diperlukan agar mampu melaksanakan amanat undang-undang yakni mencerdaskan kehidupan bangsa supaya dapat bersaing pada era globalisasi ini.

Pembaharuan sistem pendidikan ini mancakup semua komponen pendidikan seperti pembaharuan kurikulum dan proses belajar mengajar, peningkatan kualitas guru, pengadaan buku pelajaran dan sarana belajar lainnya, penyempurnaan sistem penilaian, dan juga manajemen pendidikan. Pembaharuan sistem pendidikan inilah yang menjadi tantangan tersendiri bagi negara-negara di dunia, sehingga negara-negara di dunia berlomba-lomba menerapkan berbagai macam sistem pendidikan terbaik untuk menciptakan generasi terdidik dengan kualitas unggulan, karena kemajuan suatu bangsa ditentutkan oleh kualitas masyarakatnya, semakin maju suatu bangsa dapat dipastikan kualitas masyarakat atau sumber daya manusianya juga baik.

Dalam upaya meningkatkan kualitas pembelajaran di sekolah dasar pemerintah telah melakukan berbagai macam upaya. Upaya-upaya yang telah dilakukakn tersebut diantaranya penyediaan sumber belajar yang relevan, pelatihan guru, dan penyediaan saran dan prasarana yang memadai. Selain itu, pemerintah juga rutin mengadakan revisi kurikulum secara berkala untuk memperbaiki kekurangan-

\footnotetext{
* Corresponding author.

E-mail Addresses: thu sant@yahoo.com(Putu Santra), imadecitra.wibawa@undiksha.ac.id (I Made Citra Wibawa), niwayan.rati@undiksha.ac.id

(Ni Wayan Rati)
} 
kekurangan yang ada pada kurikulum sebelumnya. Sementara itu, terkait dengan pembelajaran di sekolah, keberhasilan dalam kegiatan pembelajaran di sekolah tidak lepas dari berbagai macam faktor misalnya guru, model pembelajaran, sarana-prasarana pembelajaran, situasi dan kondisi kelas, serta faktor siswa sebagai peserta didik. Faktor-faktor tersebutlah yang menjadi kunci keberhasilan dalam kegiatan pembelajaran di sekolah. Melalui kegiatan pembelajaran siswa mulai mengalami berbagai macam perubahan yang kompleks, seperti perubahan dari segi pengetahuan, keterampilan, kecerdasan, maupun dari segi sikapnya.

Salah satu mata pelajaran di sekolah dasar yang turut serta menentukan kualitas sumber daya manusia adalah mata pelajaran IPA. Pendidikan IPA memberi kontribusi yang cukup besar terhadap perkembangan teknologi dalam berbagai sektor kehidupan di masyarakat. Dengan demikian, penguasaan terhadap IPA perlu terus ditingkatkan sehingga dapat bersaing dengan negara lain di era globalisasi ini. Untuk menunjang tercapainya tujuan pendidikan IPA harus didukung oleh proses pembelajaran yang kondusif.

Salah satu model pembelajaran inovatif yang mampu memfasilitasi siswa untuk lebih meningkatkan pemahaman konsep IPA ialah model pembelajaran think pair share. Sani \& Kurniasih, (2016:58) "model pembelajaran think pair share atau berfikir berpasangan berbagi merupakan model pembelajaran kooperatif yang dirancang untuk mempengaruhi pola interaksi siswa". Ibrahim dkk (dalam Prayudhawati, 2012) mengemukakan bahwa dalam pembelajaran kooperatif tipe Think-Pair-Share (TPS) prosedur yang digunakan dapat memberi siswa lebih banyak waktu untuk berfikir, merespon dan saling membantu satu sama lain, meningkatkan keterampilan berkomunikasi melalui diskusi kelompok dan presentasi serta dapat meningkatkan perolehan belajar siswa

Pembelajaran kooperatif tipe think pair share melibatkan siswa secara aktif dalam berfikir (think), berdiskusi dengan pasangan (pair), dan berbagi dengan teman-teman sekelasnya (share). Strategi think-pair-share (TPS) atau berpikir berpasangan berbagi adalah merupakan jenis pembelajaran kooperatif yang dirancang untuk mempengaruhi pola interaksi siswa (Kardiasih, 2013). Dalam model pembelajaran konvensional, siswa yang aktif dalam kelas hanya siswa tertentu yang benar-benar rajin dan cepat dalam memahami materi yang dijelaskan oleh guru sedangkan siswa lain menjadi "pendengar" materi yang disampaikan oleh guru. Dengan menerapkan model pembelajaran think pair share dapat meminimalisir hal ini karena semua siswa akan terlibat dengan permasalahan yang diberikan guru. Pada model pembelajaran ini tiap kelompok terdiri atas beberapa orang, sehingga siswa akan dituntut untuk ikut serta dalam pemecahan masalah (berfikir kritis) dan meningkatkan partisipasi siswa dalam kelompok sehingga siswa menjadi lebih aktif. Dengan menerapkan model pembelajaran ini siswa akan tertarik mengikuti pembelajaran karena siswa merasa ada sesuatu yang baru dalam kegiatan pembelajaran mereka yang menantang sehingga dapat membantu memecahkan masalah-masalah yang ditemukan dalam kelas sehingga siswa menjadi lebih aktif dalam kegiatan pembelajaran. Frank Layman dan koleganya di Universitas Maryland (dalam Novita, 2014) menyatakan bahwa TPS merupakan suatu cara yang efektif untuk mengganti suasana pola diskusi kelas, dengan asumsi bahwa semua resitusi dan diskusi membutuhkan pengaturan untuk mengendalikan kelas secara keseluruhan dan prosedur yang digunakan dalam TPS dapat memberi siswa lebih banyak waktu untuk berpikir, merespon dan saling membantu.

Berdasarkan hasil wawancara yang dilakukan tepatnya pada tanggal 5 sampai 7 januari 2017 dengan I Made Sumerata, S.Pd selaku kepala sekolah SD N 1 Bukti sekaligus sebagai ketua Gugus I Kecamatan Kubutambahan, beliau mengatakan bahwa Gugus I Kubutambahan terdiri dari empat sekolah yakni SD N 1 Bukti, SD N 2 Bukti, SD N 3 Bukti, dan SD N 8 Kubutambahan. Selain melakukan wawancara, observasi juga dilakukan di kelas V khususnya pada mata pelajaran IPA di SD Gugus I Kecamatan Kubutambahan untuk mengetahui aktivitas belajar dan hasil belajar siswa khususnya pada mata pelajaran IPA.

Dari kegiatan observasi kelas tersebut, ditemukan beberapa hal diantaranya: 1) Pada kegiatan pembelajaran khususnya mata pelajaran IPA guru masih menggunakan model pembelajaran konvensional dengan metode ceramah. Dalam kegiatan pembelajarannya komunikasi yang terjadi kebanyakan komunikasi satu arah yakni hanya dari guru ke siswa.Sehingga gurulah menjadi pusat pembelajaran dan guru terkesan menjadi single actor dalam kegiatan pembelajaran. Dalam mengikuti kegiatan pembelajaran juga siswa cenderung pasif. Siswa hanya duduk memperhatikan guru menjelaskan, dan sesekali menjawab jika diberi pertanyaan oleh guru, sementara beberapa siswa yang bosan akan mengalihkan kebosanannya dengan bercanda. 2) Pada kegiatan pembelajaran, guru juga masih sangat jarang menggunakan media pembelajaran. Dalam menjelaskan materi, guru hanya memberikan contoh secara lisan tanpa memberikan contoh yang konkret/nyata. Hal inilah yang tentunya menciptakan pembelajaran menjadi kurang menarik bagi siswa. 3) Tugas yang diberikan cenderung individual, masih sangat jarang menggunakan kelompok. Sehingga siswa menjadi lebih mementingkan diri sendiri dan dapat membatasi 
siswa untuk sekedar melakukan tukar fikiran atau berbagi pendapat dengan orang lain. 4) Hasil belajar yang masih kurang maksimal.

Untuk mengatasi permasalah-permasalahan tersebut, maka perlu dilakukan sebuah inovasi pada pembelajaran IPA khususnya untuk kelas V di SD Gugus I Kecamatan Kubutambahan. Inovasi yang dimaksud ialah sebuah cara guru yang dapat membuat perubahan sehingga guru dapat memfasilitasi siswa dalam belajar supaya memperoleh hasil belajar yang maksimal. Perubahan yang dimaksud yaitu mencakup perubahan peran guru dalam pembelajaran, perubahan orientasi pembelajaran, hingga perubahan ruang lingkup pembelajaran. Dengan mengubah peran guru dari transmiter menjadi fasilitator maka pembelajaran tidak lagi berorientasi pada guru tetapi akan akan berubah menjadi berorientasi pada siswa (student centered). Dengan sistem pembelajaran yang seperti ini maka siswa akan menjadi lebih aktif dalam kegiatan pembelajaran sehingga akan berdampak pada tingkat pemahaman siswa dan hasil.

Cara membuat siswa tertarik dalam mengikuti kegiatan pembelajaran ialah dengan cara membuat kegiatan pembelajaran menjadi menyenangkan. Salah satunya dengan menyampaikan bahan ajar dengan cara yang kreatif, efektif, dan komunikatif. Artinya kegiatan pembelajaran yang dilakukan dapat membuat siswa tertarik untuk belajar dan dapat menyampaikan pesan pembelajaran berupa materi pelajaran yang sesuai dengan rencana pembelajaran atau target pembelajaran yang ingin dicapai. Kereatifan guru dalam menyampaikan bahan ajar, akan berdampak pada ketertarikan siswa dalam mengikuti kegiatan pembelajaran. Untuk mendukung pelaksanaan penelitian ini, bahan ajar akan disampaikan dengan ditunjang dengan penggunaan power point yang nantinya dipadukan dengan mata pelajaran IPA. Power point dipilih karena di sekolah tempat pelaksanaan penelitian, guru masih belum pernah menggunakan power point ketika melaksanakan kegiatan pembelajaran. Hal ini tentunya menjadi hal yang baru bagi siswa sehingga antusias siswa dalam mengikuti pembelajaran akan meningkat.

Hasil-hasil penelitian tentang think pair share menyarankan bahwa penerapan model pembelajaran kooperatif tipe TPS membantu siswa untuk membiasakan bertanya kepada guru, keberanian mengemukakan pendapat, dan dapat bekerja sama dengan baik (Darlin, 2015). Khamid (2014) menemukan bahwa meningkatnya hasil belajar siswa kelas VI A SD Negeri Jetis 1 dengan model pembelajaran kooperatif tipe Think Pair Share. Hasil penelitian ini menunjukkan bahwa pelaksanaan model pembelajaran kooperatif tipe Think Pair Share terdapat peningkatan pada siklus I diperoleh nilai rata-rata kelas 76,34, siklus II nilai rata-rata kelas 80,77, dan pada siklus III diperoleh nilai rata-rata kelas 90,19. Selain itu, Jasdilla, Kuswendi \& Ramdhani (2017) juga menemuka bahwa model pembelajaran kooperatif tipe Think, Pair, Share (TPS) dapat meningkatkan hasil belajar IPS di kelas IV sekolah dasar. Hasil penelitian menunjukkan adanya peningkatan hasil belajar IPS dari 76,75\% ke 89,67\% (sangat baik).

Tujuan dilakukannya penelitian ini ialah untuk mengetahui perbedaan hasil belajar IPA antara kelompok siswa yang mengikuti kegiatan pembelajaran dengan menggunakan model pembelajaran think pair share berbantuan power point dengan kelompok siswa yang mengikuti kegiatan pembelajaran dengan menggunakan model pembelajaran konvensional di kelas V SD Gugus I Kecamatan Kubutambahan Tahun Pelajaran 2016/2017.

\section{METODE}

Penelitian ini dilaksanakan di Sekolah Dasar Gugus I Semester Genap Kecamatan Kubutambahan, Kabupaten Buleleng pada Tahun Pelajaran 2016/2017. Jenis penelitian ini ialah penelitian eksperimen semu atau eksperimen quasi. Dalam penelitian ini, populasi penelitian terdistribusi dalam kelas-kelas yang utuh, sehingga penelitian ini dikategorikan sebagai penelitian eksperimen semu. Dalam penelitian ini, unit eksperimennya berupa kelas. Penempatan subjek ke dalam kelompok yang dibandingkan tidak dilakukan secara acak. Individu subjek sudah ada dalam kelompok yang dibandingkan sebelum diadakannya penelitian. Penelitian ini menggunakan rancangan post-test only control group design.Penelitian ini membandingkan kelompok eksperimen dengan kelompok kontrol.

Koyan, (2012:30) menyatakan bahwa "populasi adalah himpunan dari unsur-unsur yang sejenis". Dalam pemilihan sampel untuk kelompok kontrol dan kelompok eksperimen, digunakan teknik simple random sampling. "Teknik simple random sampling merupakan suatu cara pengambilan sampel secara acak, dimana sampel diambil berdasarkan kelas bukan individu. Populasi yang dimaksud dalam penelitian ini ialah seluruh siswa kelas V di Gugus I Kecamatanan kubutamabahan. Sekolah yang termasuk dalam populasi dalam penelitian ini ialah SD N 1 Bukti, SD N 2 Bukti, SD N 3 Bukti, dan SD N 8 Kubutambahan, dengan jumlah siswa kelas enam sebanyak 97 siswa.

Koyan, (2012:30) menyatakan bahwa "sampel merupakan bagian dari jumlah dan karakteristik yang dimiliki oleh populasi". Sampel penelitian pada penelitian ini ialah SD Negeri 1 Bukti sebagai kelompok kontrol dan SD Negeri 8 Kubutambahan sebagai kelompok eksperimen, dengan total jumlah siswa 41 siswa. 
Salah satu faktor yang mempengaruhi hasil penelitian adalah validitas internal.Menurut Setyosari (2015) "validitas iternal bersumber dari pelaksanaan penelitian itu sendiri yang berkaitan dengan perlakuan yang diberikan apakah perlakuan yang diberikan benar-benar menyebabkan hasil yang diobservasi dalam penelitian". Validitas internal dalam penelitian ini ialah mortalitas dan instrumentasi. Kontrol terhadap ancaman yang berkaitan dengan mortalitas dilakukan dengan cara mengecek kehadiran siswa pada saat proses pembelajaran berlangsung. Namun, dalam penelitian ini ada subjek yang tidak hadir satu sampai dua kali, sehingga data post tes subjek bisa dipakai. Selanjutnya, ancaman yang berkaitan dengan instrumentasi, seperti perubahan penyusunan instrumen dilakukan dengan cara uji validitas dan reliabilitas terhadap intrumen yang disusun.

Selain faktor internal, ada faktor lain yang bersifat eksternal yang memiliki pengaruh pada hasil penelitiannya yaitu validitas eksternal.Validitas eksternal merupakan validitas yang berkaitan dengan sejauh mana hasil penelitian dapat digeneralisasi. Validitas eksternal dalam penelitian ini ialah kesahihan ekologi. Cara yang dapat dilakukan untuk mengontrol validitas eksternal ini ialah dengan cara (1) tidak memberitahukan kepada siswa bahwa mereka sedang menjadi subjek penelitian, (2) penelitian mengikuti jadwal yang berlaku di sekolah, (3) pembelajaran dilakukan oleh guru, (4) pemantauan pelaksaaan pengambilan data oleh peneliti tidak dilakukan secara terang-terangan melainkan secara diam-diam yaitu melalui pengamatan, observasi, diskusi dengan anak dan guru diluar pelajaran.

Data yang dicari dalam penelitian ini adalah hasil belajar IPA dari aspek kognitif yang diperoleh melalui post-test setelah diberikan perlakuan khusus berupa model pembelajaran think pair share dengan berbantuan power point pada kelompok eksperimen dan tanpa perlakuan khusus pada kelompok kontrol pada mata pelajaran IPA di kelas V. Metode tes dilakukan dengan membagikan jumlah tes untuk mengukur hasil belajar IPA. Untuk mengumpulkan data hasil belajar IPA tersebut digunakan metode yaitu tes. Koyan, (2007:10) menjelaskan bahwa "tes adalah instrumen/alat/prosedur yang sistematis, yang terdiri atas seperangkat pertanyaan atau tugas-tugas untuk mengukur suatu perilaku tertentu pada peserta didik dengan menggunakan bantuan skala numerik atau kategori tertentu". digunakan tes objektif dalam bentuk pilihan ganda yang terdiri dari empat alternatif pilihan jawaban (multiple choice test). Uji coba instrumen bertujuan untuk mengetahui apakah instrumen tersebut layak atau tidaknya digunakan. Dalam penelitian ini, yang di uji coba instrumennya adalah hasil belajar IPA namun untuk mengetahui layak atau tidaknya suatu instrumen maka instrumen tersebut perlu di uji coba dengan uji validitas isi, uji validitas butir soal, reabilitas tes, taraf kesukaran tes, dan uji daya beda.

Dalam penelitian ini, fokus data yang dicari adalah hasil belajar IPA yang merupakan data kuantitatif dan dianalisis dengan statistik inferensial. Statistik inferensial adalah statistik yang digunakan untuk menganalisis data dan hasilnya akan digeneralisasi pada populasi dimana sampel itu diambil. Statistik inferensial digunakan untuk mengeneralisasikan hasil penelitian yang meliputi estimasi (perkiraan) dan pengujian hipotesis.

\section{HASIL DAN PEMBAHASAN}

Analisis deskriptif dilakukan untuk mengetahui tinggi rendahnya hasil belajar siswa, baik siswa yang mengikutikegiatan pembelajaran dengan menggunakan model pembelajaranthink pair share berbantuan power pointmaupun siswa yang mengikutikegiatan pembelajaran dengan menggunakan model pembelajaran konvensional. Rekapitulasi perhitungan skor hasil belajar siswa disajikan pada Tabel 1.

Tabel 1. Rekapitulasi Perhitungan Skor Hasil Belajar Siswa

\begin{tabular}{ccc} 
& \multicolumn{2}{c}{ Hasil Belajar Siswa } \\
\cline { 3 - 3 } Statistik & Kelas Eksperimen & Kelas Kontrol \\
\hline Mean & 24,80 & 14 \\
Median & 25,75 & 13,7 \\
Modus & 27 & 13.4 \\
\hline
\end{tabular}

Bedasarkan tabel di atas dapat dideskripsikan mean (M), median (Md), modus (Mo), dari data hasil belajar IPA siswa pada kelompok eksperimen, yaitu: mean $(\mathrm{M})=24,80$, median $(\mathrm{Md})=25,75$, modus $(M o)=27$. Dari data di atas dapat disimpulkan bahwa modus lebih besar dari median dan median lebih besar dari mean (Mo $>$ Md $>M$ ), sehingga kurva yang terbentuk adalah adalah kurva juling negatifyang artinya skor cenderung sangat tinggi. Apabila distribusi data hasil belajar IPA kelas eksperimen divisualisasikan dalam bentuk grafik, maka akan tampak seperti gambar 1 berikut ini. 


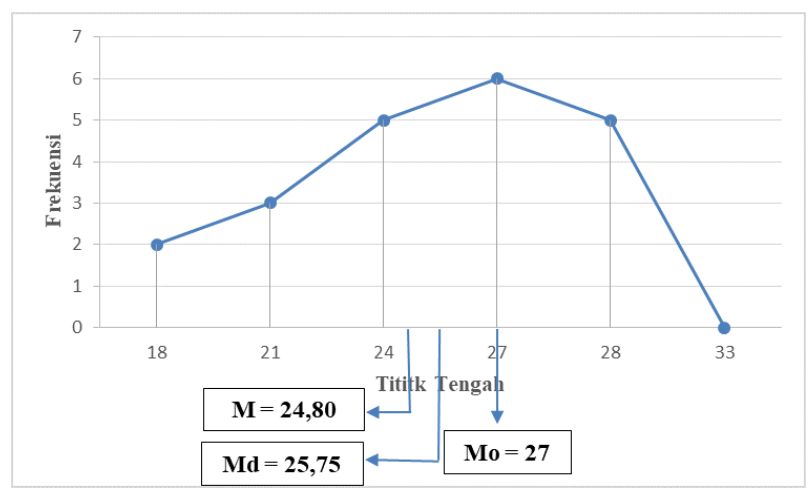

Gambar 1. Grafik Polygon Data Hasil Post-Test Kelas Eksperimen

Sedangkan data hasil belajar IPA siswa pada kelompok kontrol, yaitu: mean $(\mathrm{M})=14$, median $(\mathrm{Md})=13,7$, modus $(\mathrm{Mo})=13,4$. Dari data di atas dapat disimpulkan bahwa modus lebih kecil dari median dan median lebih kecil dari mean (Mo $<\mathrm{Md}<\mathrm{M}$ ), sehingga kurva di atas adalah kurva juling positifyang artinya skor cenderung tinggi. Apabila distribusi data hasil belajar IPA kelas kontrol divisualisasikan dalam bentuk grafik, maka akan tampak seperti gambar 2 berikut ini.

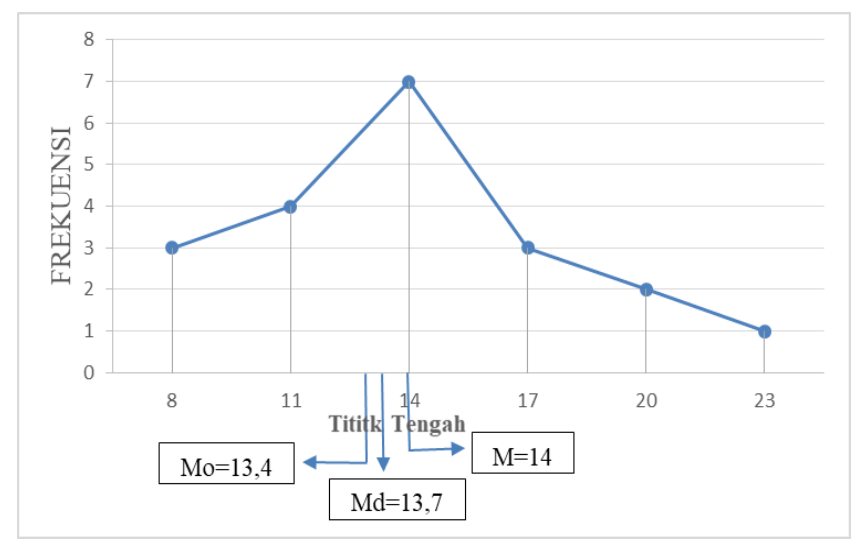

Gambar 2. Grafik Polygon Data Hasil Post-Test Kelas Kontrol

Secara deskriptif dapat disimpulkan bahwa siswa yang mengikuti kegiatan pembelajaran dengan menggunakan model pembelajaran think pair share dengan berbantuan power point lebih tinggi dari siswa yang mengikuti kegiatan pembelajaran konvensional.

Sebelum dilakukan pengujian hipotesis, terlebih dahulu dilakukan uji prasyarat yaitu uji normalitas dan uji homogenitas. Berdasarkan hasil pengujian prasyarat diperoleh bahwa data hasil belajar IPA kelas eksperimen dan kelas kontrol berdistribusi normal dan varians kedua kelas homogen, sehingga untuk menguji hipotesis menggunakan uji-t dengan rumus polled varians.

Rangkuman hasil perhitungan uji-t kelas sampel disajikan pada Tabel 2 di bawah ini.

Tabel 2. Rangkuman Hasil Perhitungan Uji-t

\begin{tabular}{clccccc}
\hline Data & \multicolumn{1}{c}{ Kelas } & $\mathbf{N}$ & $\bar{X}$ & $\mathbf{s}^{\mathbf{2}}$ & $\mathbf{t}_{\text {hitung }}$ & $\mathbf{t}_{\text {tabel }}$ \\
\hline \multirow{2}{*}{ Hasil Belajar } & Eksperimen & 21 & 24,80 & 14,74 & \multirow{2}{*}{8,24} & 1,68 \\
& Kontrol & 20 & 14 & 21,10 & & \\
\hline
\end{tabular}

Berdasarkan Tabel 2, diperoleh $t_{\text {hitung }}$ sebesar 8,24 sedangkan $t_{\text {tabel }}(\mathrm{db}=39(21+20-2)$ pada taraf signifikan $5 \%$ adalah 1,68 . Hal ini berarti $t_{\text {hitung }}>t_{\text {tabel, }}$, sehingga $\mathrm{H}_{0}$ ditolak dan $\mathrm{H}_{1}$ diterima. Sehingga dapat diinterpretasikan bahwa terdapat perbedaan hasil belajar IPA yang signifikan antara siswa kelas 
Vyang mengikuti kegiatan pembelajaran dengan menggunakan model pembelajaran think pair share berbantuan power pointdengansiswa kelas $\mathrm{V}$ yang belajar mengikuti model pembelajaran konvensional di SD Gugus I Kecamatan Kubutambahan Tahun Pelajaran 2016/2017.

Berdasarkan penelitian yang dilakukan, kegiatan pembelajaran yang dilakukan oleh kelompok siswa eksperimen dengan menggunakan model pembelajaran think pair share berbantuan power pointdan kegiatan pembelajaran menggunakan model pembelajaran konvensional yang dilakukan oleh kelas kontrol, memberikan pengaruh terhadap hasil belajar yang berbeda. Temuan penelitian yang menunjukan bahwa penerapan model pembelajaran think pair share berbantuan power point berpengaruh positif terhadap hasil belajar IPA siswa dikarenakan oleh beberapa hal.

Pertama, kegiatan pembelajaran think pair share memberikan kesempatan kepada siswa untuk membentuk sebuah kelompok dan belajar bersama. Kegiatan pembelajaran think pair share dapat membuat siswa menjadi lebih berantusias dalam mengikuti kegiatan pembelajaran. Kegiatan pembelajaran dengan model ini terdapat tiga tahapan. Tahap pertama yaitu think (berfikir), pada tahap ini siswa diajak untuk berfikir secara mandiri untuk mencari solusi terhadap permasalaham-permasalahan yang diberikan oleh guru. Pada tahap think ini, dapat melatih kemampuan siswa untuk memecahkan suatu masalah dalam pembelajaran, sehingga siswa terlatih untuk mengeluarkan ide atau pendapatnya sendiri.

Kemudian, kegiatan pembelajaran dilanjutkan dengan tahap berpasangan (pair). Pada tahap ini siswa diarahkan untuk mendiskusikan hasil pemikiran atau penyelidikan dengan kelompoknya. Pada tahap ini, siswa memadukan ide-idenya dalam kegiatan diskusi kelompok sehingga menimbulkan kesepakatan bersama berupa keputusan hasil diskusi.Kegiatan ini dapat membuat siswa menjadi lebih dekat, akrab, percaya diri, dan bertanggung jawab terhadap tugasnya yang diberikan. Pada tahap ini pula, siswa yang memiliki kemampuan yang lebih tinggi akan bertugas untuk membantu temannya yang memiliki kemampuannya lebih rendah, sehingga terjadi interaksi saling membantu satu sama lain yang dapat membuat siswa menjadi lebih aktif.

Kemudian pada tahap terakhir dilanjutkan dengan berbagi (share). Pada berbagi, siswa diarahkan untuk membagikan atau menyampaikan hasil diskusinya ke depan kelas, dengan tujuan supaya teman kelasnya mengetahui hasil diskusi kelompoknya. Pada tahap share ini dapat meningkatkan kemampuan berbicara siswa sehingga siswa menjadi lebih komunikatif. Teori ini didukung oleh Shoimin (2014:209) yang menyatakan bahwa "think pair share memiliki prosedur yang secara eksplisit memberi siswa waktu untuk berfikir, menjawab, dan saling membantu satu sama lain". Sehingga dapat disimpulkan bahwa kegiatan pembelajaran think pair share dapat membuat siswa menjadi lebih terlatih dalam pemecahan masalah, terlatih dalam mengeluarkan ide, dapat membuat siswa menjadi lebih aktif, dapat meningkatkan kemampuan berbicara dan pemahaman siswa terhadap materi yang telah dipelajari. Peningkatanpeningkatan ini berdampak pada hasil belajar siswa, sehingga hasil belajar siswa semakin meningkat. Penjelasan di atas juga diperkuat oleh temuan dari hasil penelitian yang dilakukan oleh Raditya (2015) yang menyatakan bahwa, kegiatan pembelajaran dengan menggunakan model pembelajaran think pair share dapat meningkatkan hasil belajar.

Kedua, dengan digunakannya power point dalam menunjang kegiatan pembelajaran di sekolah, dapat meningkatkan antusias siswa dalam mengikuti kegiatan pembelajaran. Hal ini terlihat dari terfokusnya perhatian siswa ketika slide power point menayangkan materi pelajaran yang sedang dipelajari. Di dalam power point yang digunakan, telah disusun serangkaian slide yang berisi teks materi, gambar, hingga video yang dapat membantu siswa dalam memahami materi. Dengan meningkatnya antusias siswa dalam mengikuti kegiatan pembelajaran, maka pengetahuan siswa juga akan meningkat. Peningkatan pengetahuan inilah yang memberi dampak pada hasil belajar siswa sehingga hasil belajar siswa menjadi lebih baik.Penjelasan di atas juga diperkuat oleh temuan dari hasil penelitian yang dilakukan oleh Yanti (2013) yang menyatakan bahwa dengan menggunakan power point dapat meningkatkan hasil belajar, karena dengan menggunakan power point dapat meningkatkan dan mengarahkan perhatian anak sehingga dapat meningkatkan motivasi belajar siswa, sehingga hasil belajar siswa meningkat.

Ketiga, dengan diberikannya penghargaan berupa gambar bintang dan tepuk tangan bagi siswa yang mampu menjawab LKS dengan benar, dapat membuat siswa menjadi lebih berantusias dalam mengikuti kegiatan pembelajaran. Meningkatnya antusias siswa ini terlihat dari kegiatan diskusi yang siswa lakukan. Siswa berlomba-lomba untuk menjawab pertanyaan dengan benar supaya mendapat rewards dari guru. Pemberian penghargaan mampu meningkatkan motivasi belajar siswa, sehingga siswa akan belajar bersungguh-sungguh. Dengan belajar bersungguh-sungguh, maka dapat meningkatkan hasil belajar siswa. Penjelasan di atas juga diperkuat oleh temuan dari hasil penelitian yang dilakukan oleh Sujiantari (2016) yang menyatakan bahwa dengan adanya reward akan berdampak baik pada siswa yaitu dapat memberikan semangat baru (motivasi) dalam melakukan kegiatan. Pendapat tersebut, sesuai dengan pendapat Sudana (2016) yang menyatakan bahwa, pemberian penghargaan berupa hadiah- 
hadiah yang dijanjikan apabila mau berbuat sesuatu akan memotivasi siswa untuk lebih aktif. Selain menguatkan hasil penelitian yang menerapkan pemberian reward, hasil penelitian ini juga menguatkan hasil penelitian yang menerapkan model pembelajaran think pair share, diantaranya penelitian yang dilakukan oleh Husni, Lasmawan \& Marhaeni (2013) bahwa hasil belajar siswa yang dibelajarkan dengan model kooperatif Tipe Think Pair Share lebih baik dibanding dengan hasil belajar siswa dengan model konvensional. Penelitian yang dilakukan oleh Aisyah (2016) juga menemukan bahwa meningkatnya hasil belajar siswa yang terjadi selama proses pembelajaran PKn dengan menggunakan model cooperative learning tipe think pair share. Hasil penelitian siklus pada I terdapat 17 siswa yang tuntas belajar dengan persentase ketuntasan 63\% dan rata-rata kelas mencapai 70,93. Pada siklus II meningkat menjadi 26 siswa yang tuntas belajar dengan persentase ketuntasan $96 \%$ serta rata-rata kelas $80,19 \%$.

Sedangkan temuan penelitian yang menunjukan bahwa pembelajaran dengan menggunakan model konvensional berpengaruh negatif terhadap hasil belajar IPA siswa dikarenakan dalam kegiatan pembelajarannya guru masih mendominasi kegiatan pembelajaran. Komunikasi yang terjadi cenderung hanya satu arah, yaitu dari guru ke siswa. Sehingga peserta didik cenderung hanya memperhatikan guru tanpa diimbangi dengan aktivitas lainnya. Penjelasan ini didukung oleh Rasana (2009:18) yang menyatakan bahwa "model pembelajaran konvensional merupakan model pembelajaran yang ditandai dengan penyajian pengalaman-pengalaman yang berkaitan dengan konsep yang akan dipelajari, dilanjutkan dengan pemberian informasi oleh guru, tanya jawab, pemberian tugas oleh guru, pelaksanaan tugas oleh siswa sampai pada akhirnya guru merasa bahwa apa yang telah diajarkan dimengerti oleh siswa".

Dengan kegiatan pembelajaran seperti ini, siswa menjadi pasif karena hanya duduk dan memperhatikan penjelasan guru tanpa diimbangi dengan aktivitas lain seperti kerja kelompok, berdiskusi, maupun membagikan hasil hasil diskusinya. Hal ini membuat siswa menjadi bosan dan tidak bersemangat dalam mengikuti kegiatan pembelajaran. Jika siswa telah bosan dan tidak bersemangat dalam mengikuti kegiatan pembelajaran, maka sangat sulit bagi siswa untuk memahami materi pelajaran yang diajarkan. Sehingga berpengaruh negatif terhadap pemahaman materi dan berdampak pada hasil belajar siswa, sehingga hasil belajar siswa menjadi buruk.

Berdasarkan paparan di atas, dapat disimpulkan bahwa kegiatan pembelajaran dengan menerapkan model think pair share berbantuan power point mampu meningkatkan kemampuan pemecahan masalah, keaktifan, antusias, dan kemampuan berbicara siswa. Sehingga berpengaruh terhadap tingkap pemahaman siswa dan hasil belajar IPA siswa kelas V di SD Gugus I Kecamatan Kubutambahan, Tahun Pelajaran 2016/2017. Maka dari itu, model pembelajaran ini dapat diterapkan sebagai variasi dalam kegiatan pembelajaran sehingga siswa tidak mudah jenuh, dan kegiatan pembelajaran menjadi lebih variatif yang pada akhirnya, hasil belajar pun dapat ditingkatkan.

\section{PENUTUP}

Berdasarkan hasil pengujian hipotesis dan pembahasan, ditemukan bahwa terdapat perbedaan yang signifikan pada hasil belajar IPA antarasiswa kelas V yang mengikuti kegiatan pembelajaran dengan menggunakan model pembelajaran think pair share dengan berbantuan power point dan siswa kelas $\mathrm{V}$ yang mengikuti kegiatan pembelajaran dengan menggunakan model pembelajarankonvensional di SD Gugus I Kecamatan Kubutambahan Tahun Pelajaran 2016/2017. Hal ini dapat dilihat pada perhitungan pengujian hipotesis melalui uji-t, dinyatakan bahwa $t_{\text {hitung }}>t_{\text {tabel }}\left(t_{\text {hitung }}=8,24>t_{\text {tabel }}=1,68\right.$, sehingga $\mathrm{H}_{0}$ ditolak dan $\mathrm{H}_{1}$ diterima. Berdasarkan rata-rata skor hasil belajar IPA, diketahui bahwa skor rata-rata siswa kelas $\mathrm{V}$ yang belajar mengikuti model pembelajaran think pair share berbantuan power point adalah 24,80 (dikategorikan sangat tinggi), sedangkan rata-rata skor siswa kelas $\mathrm{V}$ yang belajar mengikuti model pembelajaran konvensional adalah 14 (dikategorikan sedang). Hal ini berarti rata-rata kelompok eksperimen > rata-rata kelompok kontrol.

Dengan demikian, dapat disimpulkan bahwa kegiatan pembelajaran yang menggunakan model pembelajaran think pair share dengan berbantuan power point berpengaruh terhadap hasil belajar IPA siswa kelas V SD Gugus I Kecamatan Kubutambahan Tahun Pelajaran 2016/2017.

Berdasarkan hasil penelitian yang telah dilakukan, saran yang dapat disampaikan peneliti ialah sebagai berikut. Bagi guru, dalam melaksanakan proses pembelajaran IPA yang aktif dan menyenangkan, guru hendaknya dapat menambah referensi pembelajaran yang inovatif.Bagi kepala sekolah,diharapkan penelitian ini dapat menciptakan output yang optimal, hendaknya kepala sekolah mengikutsertakan guru untuk mengikuti berbagai seminar atau pelatihan-pelatihan mengenai pembelajaran inovatif. Selain hal tersebut, hendaknya kepala sekolah banyak menambah sumber-sumber belajar di sekolah. Bagi peneliti lain,penelitian ini hanya meneliti hasil belajar pada ranah kognitif. Ranah afektif, dan ranah psikomotor belum dijawab pada penelitian ini. Untuk itu, peneliti lain hendaknya dapat melaksanakan penelitian 
lanjutan mengenai ranah-ranah tersebut.Peneliti yang berminat mengadakan penelitian lebih lanjut mengenai model pembelajaran think pair share berbantuan power point dapat menjadikan hasil penelitian ini sebagai salah satu referensi untuk meneliti dalam lingkup yang lebih luas, sehingga diperoleh sumbangan ilmu yang bermanfaat dan sesuai dengan perkembangan zaman.

\section{DAFTAR RUJUKAN}

Aisyah. 2016. Penggunaan Model Cooperative Learning Tipe Think Pair Share Untuk Meningkatkan Hasil Belajar PKn Pada Siswa Kelas IV SD Muhammadiyah 3 Palu. Jurnal Kreatif Tadulako Online. Volume 4, Nomor 4 (hlm. 297-305)

Astawan, Gede. 2010. Dasar-dasar TIK. Singaraja: FIP Undiksha.

Darlin. 2015. Penggunaan Model Cooperative Learning Tipe Think Pairs Hare Untuk Meningkatkan Hasil Belajar PKN Pada Siswa Kelas V SD Inpres Duyu. Jurnal Kreatif Tadulako Online. Volume 4, Nomor 7 (hlm. 257-264)

Husni, Muhammad, W. Lasmawan \& A.A.I.N. Marhaeni. 2013. Pengaruh Model Pembelajaran Kooperatif Tipe Think Pair Share Terhadap Prestasi Belajar PKn Kelas IV SD Gugus I Selong ditinjau dari Motivasi Belajar. e-Journal Program Pascasarjana Universitas Pendidikan Ganesha. Volume 3 Nomor 1

Jasdilla, Kuswendi \& Ramdhani. 2017. Hasil Belajar dan Pembelajaran Kooperatif Tipe Think Pair Share (TPS). Jurnal Pendidikan Indonesia. Volume 6, Nomor 1 (Hlm. 96-105)

Khamid. 2014. Peningkatan Hasil Belajar Matematika Melalui Think Pair Share pada Siswa Kelas VI SD Negeri Jetis 1 Yogyakarta. Jurnal Ilmiah Guru "COPE". Nomor 02 (hlm. 8-15)

Kardiasih, Ayu, I Wyn Suwatra \& Ni Kt. Suarni. 2013. Implementasi Strategi TPS Dalam Pembelajaran IPA Dengan Menggunakan Peta Konsep Sebagai Upaya Meningkatkan Aktivitas dan Hasil Belajar Siswa Kelas V. Jurnal Mimbar PGSD Universitas Pendidikan Ganesha.

Koyan, I Wayan. 2012. Statistik Pendidikan Teknik Analisis Data Kuantitatif, Cetakan Pertama. Singaraja: Universitas Pendidikan Ganesha Press.

Mudjrimin, I. W. Lasmawan \& A.A.I.N. Marhaeni. 2013. Pengaruh Model Pembelajaran Kooperatif Tipe Thinkpair Share Terhadap Motivasi Berprestasi dan Hasil Belajar IPS Siswa Kelas V SDN Gugus 02 Kopang. ". e-Journal Program Pascasarjana Universitas Pendidikan Ganesha. Volume 3

Novita, Rita. 2014. Efektivitas Model Pembelajaran Kooperatif Tipe Think Pair Share (TPS) Pada Materi Trigonometri di Kelas XI IA1 SMA Negeri 8 Banda Aceh. Jurnal Visipena. Volume 5 Nomor 1 (hlm. 128-135)

Prayudhawati, Etik. 2012. Meningkatkan Kualitas Pembelajaran Ipa Terpadu Dengan Pembelajaran Kooperatif Tipe Think-Pair-Share (TPS) pada Tema Kesadahan Air di SMPN 1 Loceret Nganjuk. EJurnal UNESA. Volume 1 Nomor 1 (hlm. 92-100)

Raditya, I Wayan. 2015. “Pengaruh Model Pembelajaran Kooperatif Tipe Think Pair Share (TPS) Terhadap Hasil Belajar IPA Siswa Kelas VI SD Gugus Letda Made Putra Kecamatan Denpasar Utara Tahun Ajaran 2014/2015". Jurnal Mimbar PGSD Universitas Pendidikan Ganesha. Vol 3. Diakses pada tanggal 20 Juli 2017.

Rasana, Raka. 2009. Model-model Pembelajaran. Singaraja: Universitas Pendidikan Ganesha.

Sadiman, Arief S. dkk. 2005. Media Pendidikan. Jakarta: PT Raja Grafindo Persada.

Samatowa, Usman. 2010. Pembelajaran IPA di Sekolah Dasar, Cetakan Pertama. Jakarta: PT Indeks.

Shoimin, Aris. 2014. 68 Model Pembelajaran Inovatif dalam Kurikulum 2013, Cetakan Pertama. Yogyakarta: Ar-Ruzz Media.

Sujiantari, Ni Kadek. 2016. "Pengaruh Reward dan Punishment Terhadap Motivasi Belajar Siswa Dalam Pembelajaran IPS (Study Pada SMP Negeri 1 Singaraja Kelas VIII Tahun Ajaran 2015/2016)". Jurnal Jurusan Pendidikan Ekonomi Universitas Pendidikan Ganesha. Vol 7. Diakses pada tanggal 20 Juli 2017.

Suprijono, Agus. 2009. Cooperative Learning, Cetakan Pertama. Yogyakarta: Pustaka Belajar. 
Susanto, Ahmad. 2013. Teori Belajar dan Pembelajaran di Sekolah Dasar, Edisi 1, Cetakan Pertama. Jakarta: Kencana Prenadamedia Group.

Sutarminingsih, Ni Pt. Evi. 2013. "Pengaruh Model Pembelajaran Think Pair Share (TPS) Terhadap Hasil Belajar IPA Siswa Kelas V SD Negeri Kubutambahan Kecamatan Kubutambahan". Jurnal Mimbar PGSD Universitas Pendidikan Ganesha. Diakses pada tanggal 20 Juli 2017.

Sutrisni, Ni Wyn. Paris. 2013. "Pengaruh Model Pembelajaran Kooperatif Tipe Think Pair Share Berbasis Sains Teknologi Masyarakat Terhadap Hasil Belajar IPA Siswa Kelas V SD”. Jurnal Mimbar PGSD Universitas Pendidikan Ganesha. Diakses pada tanggal 20 Juli 2017.

Yanti, Ni Wayan Widya. 2013. "Penerapan Model Pembelajaran PBL Berbantuan Power Point Untuk Meningkatkan Hasil Belajar PKn”. Jurnal Fakultas Ilmu Sosial Universitas Pendidikan Ganesha. Vol 3. Diakses pada tanggal 20 Juli 2017. 